\title{
A Brief Analysis of College English Teaching Method under the Micro-course Model
}

\author{
Fan Yazhen \\ School of Foreign Studies, Xi'an University, Xi'an 710065
}

Keywords: Micro-class, College English; Teaching

Abstract: In recent years, with the continuous development and popularization of computer and network technology, teaching methods in some aspects have undergone earth-shaking changes. Micro-teaching is a brand-new teaching model. Micro-teaching originated in foreign countries and has been popularized and applied in many colleges and universities since it was introduced into China. From the actual effect, micro-lesson is in line with the characteristics of the times, in line with the students learning habits, and welcomed by the majority of students. In the new historical period, how to introduce the micro-teaching mode into college English teaching and further exert the effect of micro-teaching is a historical task for the college English educators.

Traditional College English teaching is carried out mainly by means of classroom teaching. On the one hand, it is restricted by the progress of the course, on the other hand, it is restricted by the class time In Traditional College English teaching, it is difficult for a teacher to explain the characteristics of different students and the degree of their digestion and comprehension of Knowledge This creates a disconnect between what the teacher is teaching and what the students are learning.

Micro-lesson, from its name, it is a short course, and short and concise is the most notable feature of micro-lesson. Micro courses are generally around the content of a knowledge point or difficult point to tell the story. The length of the micro-lesson is generally controlled at about ten minutes. Micro class seems very small, but its role is very powerful. At present, the production of micro courses has shown the trend of modular development.

\section{Analysis of the characteristics of micro-courses}

Miniaturization is the most basic characteristic of micro-teaching. The video recorded by teachers on the explanation of a knowledge point is the simplest model of micro-lesson. Micro-course content is very rich, not only limited to the aspect of classroom teaching. Generally speaking, the micro-class content can be composed of classroom teaching, extracurricular practice, student feedback information, teachers on the knowledge point of the evaluation. Compared with traditional classroom teaching, micro-teaching has great advantages. First of all, micro-teaching is more flexible, diverse, and it not limited to the traditional classroom teaching method of education. Teachers can concentrate on explaining a knowledge point through the micro class, or the teaching content into pieces, so that students can grasp and learn. Second, micro-class content is very 
prominent, mainly for a knowledge point to explain, so that students learn to have more targeted. The length of micro-classes are generally controlled at about 10 minutes. If the time is more than 10 minutes, micro-class will generally be divided into different parts of micro-classes. Studies have shown that the effective length of time for which a person can concentrate is about ten minutes. Ten minutes of micro-class, just to allow students to focus on the state of knowledge in the State of completion of the study. Our traditional classroom teaching is typically forty-five 30 minutes And in the classroom, we have also found that even the most attentive students are distracted for a while. The micro-courses have a clear theme in terms of content. They are developed for a certain knowledge point, and the content of the classroom teaching is transformed into a scattered and personalized component. At present, in the domestic university disciplines, the content of the micro-course mainly focuses on a certain knowledge point, a certain problem, a certain link or a certain teaching unit. The focus of the micro-course design is not only on the teacher's teaching, but also more pay attention to the students' learning. The content of the micro-course should be as simple and easy to understand as possible, and it is easy for students to digest after class. At the same time, the learning of micro-courses is not limited by time and space. When conditions permit, students can browse the micro-course content anytime and anywhere by simply opening the network terminal or mobile client. Students are most aware of their learning status, and they can selectively learn independently, which greatly enhances students' learning efficiency.

\section{The promoting effect of micro-teaching on college English Teaching}

Micro-teaching plays a significant role in promoting traditional college English teaching.

\subsection{Promote the change of college English Teaching Concept}

Although the micro-class started late in China, after these years of development, it has been widely recognized in the educational sector. The promotion of micro-lesson to traditional education and teaching is firstly embodied in its new educational and teaching idea which breaks the bondage of traditional thinking. After years of development, China's higher education has made remarkable achievements in many aspects But in the new era of Social Development and change, many traditional ideas and ideas in our higher education have fallen far short of the requirements of the times and the goals of talent cultivation. The emergence of micro-courses is a kind of warning, telling us that in the development of computer technology and information technology, more and more new educational teaching methods and methods are affecting higher education teaching under globalization in an unstoppable situation. If we face college teaching with a backward vision and a self-styled attitude, then the gap between us and our foreign counterparts will only gradually increase. At the same time, in advocating the liberal education today, the traditional education teaching in the accumulated abuse has been widely criticized, micro class application as a window to let us see the new technology under the direction of higher education teaching reform and progress. This kind of ideological reversal is the basis for us to deepen the reform of education and teaching, and the reform of education and teaching is moving forward smoothly.

\subsection{Balance the differences in students' learning}

Each student has his own characteristics. We've always had a pretty good idea of that. However, due to the limitation of teaching progress and teaching time, it is difficult to accommodate different students' learning progress and personal interests. It's a question that's been bothering us for a long time. It is against this background that the liberal education was proposed. Micro-lesson has great flexibility, which not only exists in its teaching content, but also in its form. In classroom teaching, 
students can write down the problems they don't understand at any time, and make inquiries and study in the micro-lesson system after class. At present, the construction of campus network has reached a considerable scale, and basically campus network has covered the scope of students' work and study. As long as there is a terminal, students will be able to fill in the gaps at any time and any place completely breaking the traditional learning time and space constraints.

Higher English course is a practical course. However, in the past, with the teacher as the teaching center, the students' enthusiasm and initiative are difficult to be mobilized, and the students are basically in a passive learning state. The introduction of micro-courses transforms the center of learning from a teacher to students. Students can learn new knowledge by previewing,studying, and reviewing. In this process, students' knowledge application ability and independent thinking ability have been greatly improved. The practice also proves that micro-class can improve students' ability of language mastery and application, self-study and independent thinking

Young students are in a period of curiosity about new things. As a new way of teaching,micro-class can fully arouse students' interest in learning.Of course, we can also allow students to fully participate in the micro-class production. As liberal arts teachers,although we have a deep cultivation in their own professional direction, as liberal arts teachers of the common disease,they generally do not have a full grasp of new technologies such as computers. The computer field is the specialty of college students, who have a mastery of computers. Let students participate in the production of micro-courses.on the one hand, enhancing students' sense of participation in learning can maximize the enthusiasm and initiative of students, and also exercising the students' hands-on ability,which can be described as two birds with one stone.

\section{The application of micro-teaching in higher English teaching}

The application of micro-courses in higher English teaching is not only the requirement of curriculum reform,but also the requirement of the development of college English teaching itself.The author has been engaged in higher English teaching for many years.According to the author's observation and analysis,I think the construction of college English teaching should focus on the following aspects:

\subsection{Attach great importance to the making of micro-courseware}

Micro-courseware as a micro-teaching mode of the most basic components of the quality of micro-courseware directly affects the teaching results. We should fully realize the importance of micro-courseware,attach importance to the production and development of micro-courseware,and integrate the teaching content into the micro-curriculum system as much as possible.In the courseware content making,teachers should combine the teaching goal,students' learning foundation and curriculum requirements to make the corresponding micro courseware content.Of course,we have to give full consideration and attention to the content of the learning difficulties,so as to take into account both the learning characteristics of individual students and the learning needs of most students. We should follow the principle of step by step,stress the key points of the course,grasp the teaching rhythm and leave enough time for students to digest and absorb.

At present,many disciplines of micro-courseware made by the professional teachers or students to complete.One of the problems is that the quality of micro-courseware is not uniform,and many rough micro-courseware into the teaching process.How to solve this problem?I think we should establish the admittance standard or making requirement of micro-courseware as early as possible.Only in this way,the scientific and educational nature of micro-courseware can be fully protected. 


\subsection{Pay attention to the collection of micro course teaching resources}

Micro-class is rich in content,and the form of expression is more diverse,generally including sound and image information.The choice of teaching resources is very important in making and configuring micro-lessons.As teachers, we have to collect a wide range of curriculum-related teaching resources. The channel of collecting teaching resources can be network or other forms. For the collection of educational and teaching resources,we should be fully considered,and should not be entirely taken.Not processed teaching resources generally do not easily put into the micro-courseware.In the information-based conditions,micro-teaching resources should be classified storage,in case of emergency needs.Some colleges have dedicated servers for micro-teaching resources, and teachers and students can put the resources they collect that are closely related to teaching into a special directory.The collection of micro-lesson teaching resources to work hard at ordinary times,avoid cramming. When selecting the teaching resources of micro-teaching,we must proceed from the actual situation,starting from the needs of the students,and try to select the content that the students like to see and hear.Through these teaching resources,we can effectively narrow the distance with the students.

\subsection{Pay attention to the construction of the interactive system of micro-courses}

When we are building a micro-class system,there is a link is relatively easy to be ignored,that is the interactive function of the micro-class learning system.Interactivity,as the name suggests, is the timely exchange of information between two or more parties.Students in the process of learning micro-lessons, if only one person to study,then in this process is easy to have a sense of fatigue and confusion.The establishment of interactive system is very helpful to achieve the communication between students,teachers and students. One of the disadvantages of Traditional College English teaching is that the interaction between teachers and students is not strong. The teaching and learning that teachers and students build is a two,how this educational environment can produce learning effectiveness.Building an interactive system in the micro-course allows students to have discussions and interactions between teachers and students, and teachers can also answer questions through this platform also answer questions through this platform. We can also use this system to collect the views and suggestions of students on micro-courseware in time,and find out the deficiencies in the construction of micro-curriculum system,so as to adjust and correct them in time.

\section{Conclusion}

With the development of the economy and the progress of the society, the requirements of the State for the training of talents are constantly rising. How to do a good job in the new historical period is not only related to the long-term development of the subject, but also related to the success or failure of the teaching reform. In the new historical period, the advancement of science and technology has provided the good platform for the promotion of education and teaching efficiency. The form of micro-class not only accords with the characteristics of students' learning, but also optimizes the teaching mode in a simple and flexible way effectively improve the quality of college English teaching. How to do well the reform of college English teaching under the micro-course mode still needs to be improved. We should do this work well with a high sense of mission and responsibility, and contribute to the healthy development of college English teaching.

\section{References}

[1] Du Xue.On the application of micro-teaching in college English Teaching [J] The theory, 2014,(29) 
[2] Li Hui.On the application of micro-teaching in college English Teaching [J] Consumer Guide, 2015,(7)

[3] Shi Yanlan and Luo Juan.To explore the application and misunderstanding of micro-teaching in college English Class [J] New Course Learning (Part II), 2015,(05)

[4] Xiaoli Zhang.On the application of micro-lessons in Business English Teaching [J].English teacher, 2015,(21)

[5] Li Yao.The effective application of micro-lessons in college English Teaching [J].Reading and writing (Journal of Education and teaching), 2016, (01)

[6] Du Yiheng.On the application of micro-teaching in college English Teaching [J].New Silk Road (late), 2016,(04)

[7] Zheng Xiaojun,Zhang Xia. Effective web-based learning:ideas,paths and strategies [J].Audio Visual Education in China,2012(10)' 